Portland State University

PDXScholar

1978

\title{
The use of track autoradiography to determine species-specific phytoplankton productivity
}

Ralph Martin Vaga

Portland State University

Follow this and additional works at: https://pdxscholar.library.pdx.edu/open_access_etds

Part of the Biology Commons

Let us know how access to this document benefits you.

\section{Recommended Citation}

Vaga, Ralph Martin, "The use of track autoradiography to determine species-specific phytoplankton productivity" (1978). Dissertations and Theses. Paper 2835.

https://doi.org/10.15760/etd.2829

This Thesis is brought to you for free and open access. It has been accepted for inclusion in Dissertations and Theses by an authorized administrator of PDXScholar. Please contact us if we can make this document more accessible: pdxscholar@pdx.edu. 
AN ABSTRACT OF THE THESIS OF Ralph Martin Vaga for the Master of Science in Biology presented February 28, 1978. Title: The Use of Track Autoradiography to Determine Species-Specific Phytoplankton Productivity APPROVED BY MEMBERS OF THE THESIS COMMITTEE:
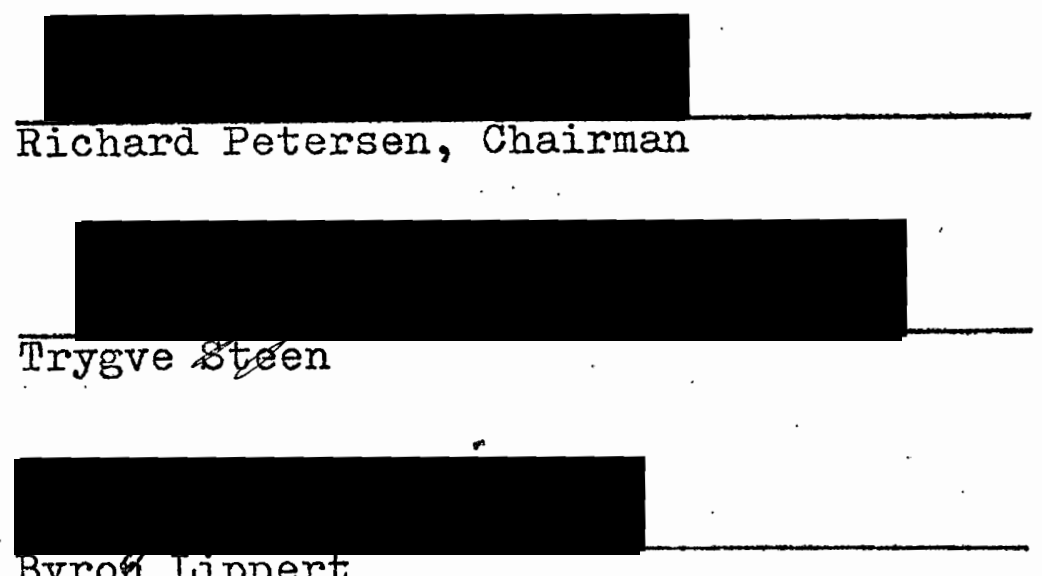

Methods of measuring primary productivity are discussed in terms of what information they provide concerning energy flow in the phytoplankton community. A track autoradiographic technique is presented which measures species-specific phytoplankton productivity and its use is demonstrated under laboratory conditions. Controls and standardized processing conditions are established which permit the use of the track technique in quantitative evaluations of primary productivity. 
THE USE OF TRACK AUTORADIOGRAPHY TO DETERMINE SPECIES-SPECIFIC PHYTOPLANKTON PRODUCTIVITY

\section{by}

Ralph Martin Vaga

A thesis submitted in partial fulfillment of the requirements for the degree of

MASTER OF SCIENCE

in

BIOLOGY

Portland State University

1978 
TO THE OFFICE OF GRADUATE STUDIES AND RESEARCH:

The members of the Committee approve the thesis of Ralph Martin Vaga presented February 28, 1978.

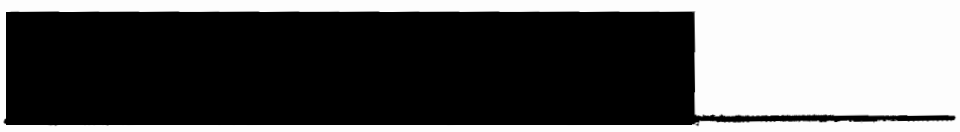

Richara Petersen, Chairman

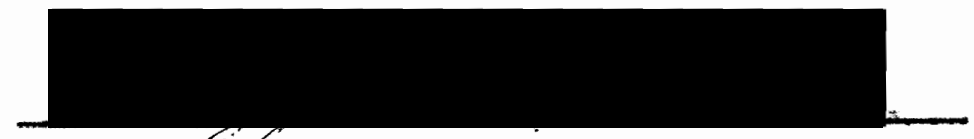

Trygre Steen

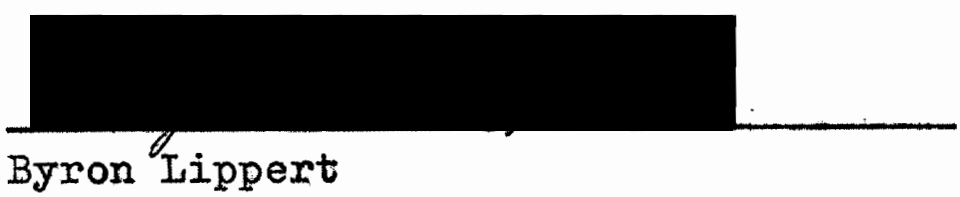

\section{APPROVED :}

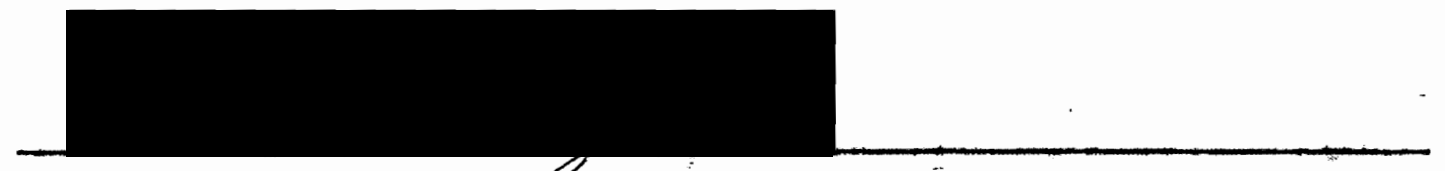

Herman Paylor, Head, Bepartment of Biology

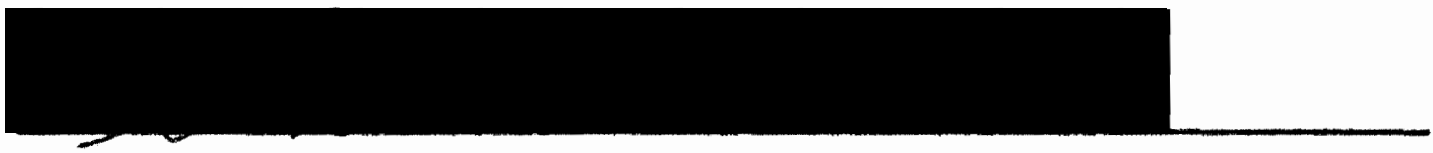

Stanley E. Rauch, Dean of Graduate Studies and Research 


\section{ACKNOWLEDGMENTS}

I would like to express my thanks to Drs. Steen and Iippert for their assistance in the technical aspects of this thesis and to Dr. Clarkson for his assistance in data analysis. Also, a special thanks to Dr. Petersen whose inspiration and guidance made the entire undertaking possible. 
TABLE OF CONTENTS

PAGE

ACKNOWLEDGMENTS •. • • • • • • . . .

IIST OF TABLES •. • . • • • • • • • . V v

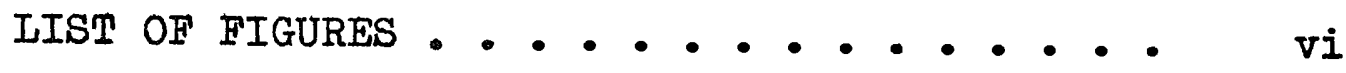

INTRODUCTION •. • • . . . . . . 1

MATERIAIS AND METHODS •. . . . . 10

Culture techniques . . . . . 11

Labelling of Cells . . . . . 11

Autoradiography ... . . . 12

RESULTS • • • • • • • • • • • 23

REPERENCES •. •. •. . . . . . 31 


\section{IIST OF TABIES}

TABIE

PAGE

I Comparison of observed and expected number of tracks per cell for

Selenastrum capricornutum . . . 22

II The mean number of tracks scored for

Selenastrum and Chlorella for

each of four exposure times . . 26 


\section{IIST OF PIGURES}

FIGURE

PAGE

1 The reduction in number of background grains as a function of length of exposure to $\mathrm{H}_{2} \mathrm{O}_{2}$ vapors .... 15

2 Relation between tracks per cell

and drying time ..... . 17

3 Relation between number of tracks per

cell versus development time . . 18

4 Phase contrast photomicrograph of

Selenastrum cell in developed

autovadiograph . . . . . . 20

5 Relation between average number of

tracks per cell and exposure

time for Selenastrum . . . . 24

6 Relation between average number of

tracks per cell and exposure

time for Chlorella

7 Relation between average number of

tracks per cell and exposure

time for Selenastrum . . . . 28 


\section{INTRODUCTION}

The structure of the phytoplankton community is highly dynamic and of varying complexity. The phytoplankters are ephemeral, their presence and relative abundances depending on a number of environmental factors, a change in any one of which can radically alter the species composition of the community over a short period of time. The overall primary productivity of the community determines its capacity to produce organic matter. The resulting build-up and distribution of energy rich compounds determines community structure and greatly influences the entire trophic system. The differential productivity of the various components is manifest in community dynamics.

The primary producers have the ability to synthesize, at the expense of an external energy source, organic compounds from inorganic precursors in amounts exceeding their direct metabolic needs. Primary production is the weight of new organic matter created by these synthetic processes. Primary productivity is the rate of production (Westlake, 1969). Productivity is divided into gross and net amounts. Gross productivity is the rate of production of new organic matter or the total amount of energy flowing into the community. 
It is equal to the observed change in biomass, plus all losses (e.g. predation and sinking) including respiration, per unit time. Net productivity is the rate of accumulation of new organic matter or the amount of energy stored in the community. This is equal to the observed changes in biomass, minus losses due to respiration, per unit time.

An empirical relationship describing primary productivity is given by (Leith, 1976):

nutrients + light + water $\rightarrow$ biomass + oxygen + energy This equation summarizes the photoautotrophic conversion of nutrients into organic matter. The rates of the physiological reactions represented by this equation indicate rates of energy flow. In natural systems they are controlled by the interaction of many factors, which may be divided into three groups (Brylinski and Mann 1973; Findenegg, 1969): 1) Climatic factors, which depend directly or indirectly on solar radiation, e.g. light conditions, temperature, mixing and turbulent action by the wind, 2) nutrient content of the euphotic zone, which depends upon the geology of the drainage area and influx of allochthonous organic material, and 3) the interaction of organisms present in the plankton community, which influences the production of certain species. As applied to the community as a whole the 
primary productivity equation is a measure of how rapidly energy is entering the system. As applied to the individual species in the community it is an indication of a species physiological status and indicates pathways of energy flow within the community. While photosynthesis is central to productivity, they may not be synonomous in terms of energy flow. For example, nitrogen starved Chlorella divert a substantial amount of photosynthetic reducing power from carbon reduction to the reduction of nitrate to nitrite (Thomas, 1977).

The quantitative evaluation of primary productivity involves measurement of the change over time of one or more of the terms of the productivity equation. Early research in primary productivity was concerned with measurements of biomass accumulation. Current research is directed toward rate measurementsof nutrient uptake or oxygen evolution. The techniques discussed below are presently in routine use in aquatic productivity research. They are used to determine gross movements of matter within the community as they relate to photosynthetic activity.

Mothodologies for estimating biomass concentrations are numerous: cell numbers, wet or dry weight, chlorophyll a concentrations, mineral content, and others (Vollenweider, 1969). As the size of the standing crop is a result of an interplay between growth rate, 
predation and sinking rates, biomass is a measure of the net amount of energy capital in the community (Cooper, 1973; Sheldon and Sutcliffe, 1973). There does not appear to be a straightforward relationship between the size of the standing crop and its productivity (Findenegg, 1969; Malone, 1971).

In the iodometric technique changes in the dissolved oxygen concentration of the medium provide an estimate of primary productivity (Winkler, 1888). Samples of the phytoplankton community are incubated in three dissolved oxygen (D.O.) bottles, one of which is opaque. The oxygen concentration in one of the light bottles serves as the control. With the change in the dissolved oxygen concentration in the other bottles, the gross and net productivity of the community is calculated. Such measurements are limited to communities which have a productivity of at least $7.5 \mathrm{mg} \mathrm{O} \mathrm{m}^{-3} \mathrm{hr}^{-1}$ (Goldmand, 1968). In less productive environments the long incubation periods required result in nutrient depletion or growth of attached bacteria which may invalidate the results.

With estimates of the photosynthetic quotient (moles $\mathrm{O}_{2}$ liberated/moles $\mathrm{CO}_{2}$ incorporated), the gross productivity reveals the total amount of energy entering the community, while the net productivity is the fraction which goes into the build-up or maintenance of community 
structure. Under natural conditions the gross productivity is a combination of the energy flux into the autotrophic and heterotrophic communities. Net productivity is something less than the amount of energy entering into the structure of the phytoplankton community. Estimates of primary productivity based on the use of nutrient uptake center on the rate of carbon fixation. While phosphorous and nitrogen have been used in productivity research (Atkins, 1923; Riley, 1944; Slawyk, 1977), with the development of a radioactive tracer technique using carbon-14 (Steeman-Nielsen, 1952), carbon fixation has come into widespread use as a method of measuring primary productivity (Culver and Brunsill, 1969; Tilzer, 1973). Samples are incubated in paired light and dark D.O. bottles each of which is inoculated with $\mathrm{Na}^{14} \mathrm{CO}_{3}$ to an appropriate specific activity. Following incubation the amount of tracer taiken up by the phytoplankton in both light and dark bottles is measured. The difference between the two provides an estimate of the uptake of carbon into the particulate fraction of the community as well as the amount of organic matter released into the medium (Fogg and watt, 1965). There is some controversy concerning what the dark bottle in the ${ }^{14}$-productivity measures and hence whether this technique estimates gross or net productivity (Morris et al, 1971). Nevertheless, 
this method provides the most sensitive estimate of primary productivity. A minor deficiency lies in the fact that, unlike the oxygen method, the dark bottle does not provide an estimate of community respiration.

These techniques are used to measure either net production or gross or net productivity from which inferences are drawn concerning energy flux through the community but provide little information on energy flow within the community. The structural complexity and dynamic nature of the phytoplankton community is based upon the collective species responses to the environment, which are in turn a function of individual species physiological adjustments. As an estimate of this physiological activity the measurement of the primary productivity of the individual species in the community would provide information concerning pathways of energy flow within the community. When viewed in light of changing environmental variables these data could be of value in constructing models of community structure, e.g. species composition and abundances, and community dynamics, e.g. patterns of succession and coexistence.

The following sections describe an autoradiographic technique which measures species-specific phytoplankton productivity in terms of rates of carbon fixation. 
In the autoradiographic technique biological specimens are labelled with a radioactive tracer after which they are placed on a microscope slide and coated with a Iiquid nuclear emulsion. Upon drying the emulsion is sensitive to ionizing radiation: the decay of a particle from the isotope is recorded in the emulsion as a latent image which, after development, becomes a visible silver grain. Depending on processing conditions the uptake of tracer may be monitored at the tissue, cellular, or subcellular level. The use of liquid emulsions to measure the radioactivity of biological specimens has been carried out along three different lines: through densitometric evaluation of random grain autoradiography, through grain counting, and through track counting. The first mentioned technique provides a measure of the beta flux reaching the emulsion per unit time, based on a unit area of emulsion or specimen (Berriman, 1952). This method is of value in measuring rather large amounts of radioactivity o ver large areas and is limited in use to histological specimens.

In grain counting the specimen is covered with a thin layer (less than 5 microns) of emulsion. The decay event is recorded, upon development of the emulsion, as a single grain. The qualitative evaluation of individual algal species productivity has been undertaken by a number of investigators (Maguire, 1971; 
Watt, 1971; Stross and Pemrick, 1974). While grain density autoradiography is of qualitative value under suitable conditions, in practice the difficulty of establishing proper controls and standardized processing conditions reduce its value in quantitative evaluations of primary productivity (Knoechel and Kalff, 1976). Quantitative evaluation of autoradiographs on the basis of track counting has been carried out in the case of alpha emmiters, e.g. Ra and Th deposited in bone tissue (Levi, 1951; 1954) and beta emmiters, e.g. phosphoraus in viral DNA (Levinthal, 1957). In track autoradiography the specimen is covered with a thick layer (25 microns or more) of emulsion. In such preparations a decay event is recorded as a string of silver grains, termed a track (Rogers, 1969). Track counting lends itself more readily to calculation of disintegration rates, particularly if the isotope is evenly distributed throughout the specimen and selfabsorption corrections can be applied. In addition, a high resolution is achieved because the response of the emulsion to a decay event is unique.

Track autoradiography has been adapted for use in quantitative measures of the carbon fixation rates of populations of algal cells (Gutelmacher, 1975; Knoechel and Kalff, 1976). Cells are incubated in a medium containing carbon-14 after which they are placed 
on a microscope stide and covered with nuclear track emulsion. After processing, the number of decay events from individual cells is observed microscopically and the average decay rate for the population is calculated. In this way the rate of carbon uptake into the particulate fraction is determined at the specific level. The research reported here is concerned with: 1) establishing controls and standardized processing conditions for the use of track autoradiography in quantitative evaluations of species-specific phytoplankton productivity and 2) demonstration of its used in mixedspecies cultures. In adaition, the uptake of tracer in the dark bottle of the ${ }^{14} \mathrm{C}$-productivity method is investigated using autoradiography. 


\section{MATERIALS AND METHODS}

\section{Culture Techniques}

Standardization of the autoradiographic technique is facilitated by using test organisms in a known physiologic state. The following culture conditions produce populations with a constant intrinsic rate of increase.

A green alga, Selenastrum capricornutum, is cultured in two litre culture flasks containing $600 \mathrm{ml}$ of EPA (NAAM) medium (EPA, 1971). Culture medium is made up fresh from concentrated stock solutions of nutrients before each transfer. The cultures are placed on a Fermentation Design Rotary Shaker and are shaken at $100 \mathrm{rpm}$ at $22^{\circ} \mathrm{C}$ under cool white fluorescent lights with a 16 hour photoperiod. Under these conditions the maximal growth rate for Selenastrum is 1.89 doublings per day. Cultures are transferred as carrying capacity. is approached.

Labelling of Cells

Labelling of cells is carried out when cultures are in log-phase growth. The culture is divided between two $300 \mathrm{ml} \mathrm{D.0.} \mathrm{bottles,} \mathrm{one} \mathrm{light} \mathrm{the} \mathrm{other} \mathrm{dark.} \mathrm{Each}$ bottle is inoculated with a $1 \mathrm{ml}$ solution of $\mathrm{Na}^{14} \mathrm{CO}_{3}$ to 
provide a medium of appropriate specific activity. These samples are incubated under normal culture conditions for two hours.

To determine uptake of the tracer into the particulate fraction through scintillation coulting, $5 \mathrm{ml}$ of sample are removed from each D.O. bottle and are placed in scintillation vials. The $\mathrm{pH}$ of each subsample is brought to 4.0 with $.05 \mathrm{ml}$ of $0.1 \mathrm{~N}$ HCL and air is gently bublied through tie sample for 15 minutes. This removes essentially all remaining inorganic carbon (Schindler, 1972). The samples are then suspended in $10 \mathrm{ml}$ of a scintillation fluor, Aquasol-2, after which the activity of each is determined by counting in a Unilux-II-A scintillation counter. The amount of tracer rele:ased into the medium as dissolved organic matter is determined by counting $5 \mathrm{ml}$ of filtered medium after removal of inorganic carbon (Fogg and watt, 1965). The cell concentration in the $\mathrm{D.O}$. bottle is determined through ten cell counts using a hemocytometer.

The combined counting efficiency and quenching due to water and biological material is determined by tice internal standard method. The efficiency of a standard volume sample without cells is constant at $87 \%$. The quenching due to algal cells is determined over the range of cell concentrations used. Volumetric disintegration rate for uptake of tracer into the particulate 
fraction is calculated by,

$$
\frac{(\mathrm{cpm} \text { light bottle })-(\mathrm{cpm} \mathrm{dark} \mathrm{bottle})}{(\text { total eff. })(\mathrm{ml} \text { sample })}=\mathrm{dpm} \mathrm{ml}^{-1}
$$

assuming the absence of activity in the dissolved organic fraction.

\section{Autoradiography}

The frosted end slides used in autoradiography are cleaned by soaking overnight in a solution of $50 \mathrm{~g}^{-1}$ $\mathrm{K}_{2} \mathrm{CrO}_{3}$ dissolved in $100 \mathrm{ml}$ of $\mathrm{H}_{2} \mathrm{SO}_{4}$. This is followed by rinsing in tap water for 30 minutes with a final distilled water rinse. The slides are allowed to dry in a dust free atmosphere after which they are dipped into a filtered solution of $500 \mathrm{mg} \mathrm{I}^{-1}$ gelatin and $0.5 \mathrm{mg}^{-1}$ chrome alum. The back of the slides are wiped clean following which they are air dried. Dust and other contaminents must be prevented from settling on the slides as the efficiency of the emulsion may be adversely affected. The gelatine provides a firm base for the adhesion of the sample as well as preventing the emulsion from separating from the slide during development.

For autoradiographic analysis $10 \mathrm{ml}$ of sample are removed from the labelled culture, acidified, and the inorganic carbon removed. The cells are allowed to settle and are resuspended in $4 \mathrm{ml}$ of a $100 \mathrm{mg} 1^{-1}$ solution of gelatin. is few drops of the sample are 
then placed on a microscope slide and spread over the surface with a glass rod. After evaporation of the water the cells firmly adhere to the slide. The cell distribution is checked to ensure both adequate numbers of organisms per slide and low enough density: the cells must be far enough apart (approximately 15 microns) to ensure that tracks from adjacent cells are distinguishable.

Kodak NTB-3 nuclear track emulsion is the emulsion of choice because of its high sensitivity and small grain size (Kodak, 1976). While the Ilford emulsions are suitable for use in autoradiography, they become fogged during deliver (Mckinely, personal communication, 1975).

All procedures in the darkroom are carried out in absolute darkness. A Kodak No. 2 safelight may be used for a short time with minimal effect. However, a dry NTB-3 emulsion will experience a substantial increase in background grains when placed near this safelight.

Slides to be dipped are placed on a cold metal plate. The polyethylene bottle containing the NTB-3 is placed in a water bath at $40^{\circ} \mathrm{C}$. After the emulsion liquifies (gel point about $25^{\circ} \mathrm{C}$ ) $20 \mathrm{ml}$ are slowly removed with a plastic syringe and placed in a dipping vial. The bottle of $\mathrm{NTB}-3$ is removed from the water bath 
while the emulsion to be used is allowed to reach $40^{\circ} \mathrm{C}$. This takes a total of about 45 minutes. The thickness of the dry emulsion covering the specimen is adjusted by varying the temperature of the dipping bath.

The slides are then dipped, one at a time, into the emulsion for 2 seconds, removed, immediately held horizontally, and the back of the slide wiped clean. They are then returned to the metal plate and the emulsion is allowed to gel. This requires about 30 minutes. When the emulsion has gelled, the slides are placed in a dessicator and dried under vacuum for 2.5 hours.

When the emulsion is dry the slides are removed from the dessicator and are placed under vapors of a 3.5\% solution of $\mathrm{H}_{2} \mathrm{O}_{2}$ for 6 hours (Caro, 1968). The high background levels usually present in the emulsion are substantially reduced by the oxidizing effect of the hydrogen peroxide. Figure 1 illustrates the reduction in background grains as a function of length of exposure to the vapor of the peroxide solution. Exposures of 20 hours or longer result in a disruption of the emulsion matrix.

The slides are then returned to the dessicator and dried under vacuum for three hours to remove water and excess peroxide. A drying time of three hours 


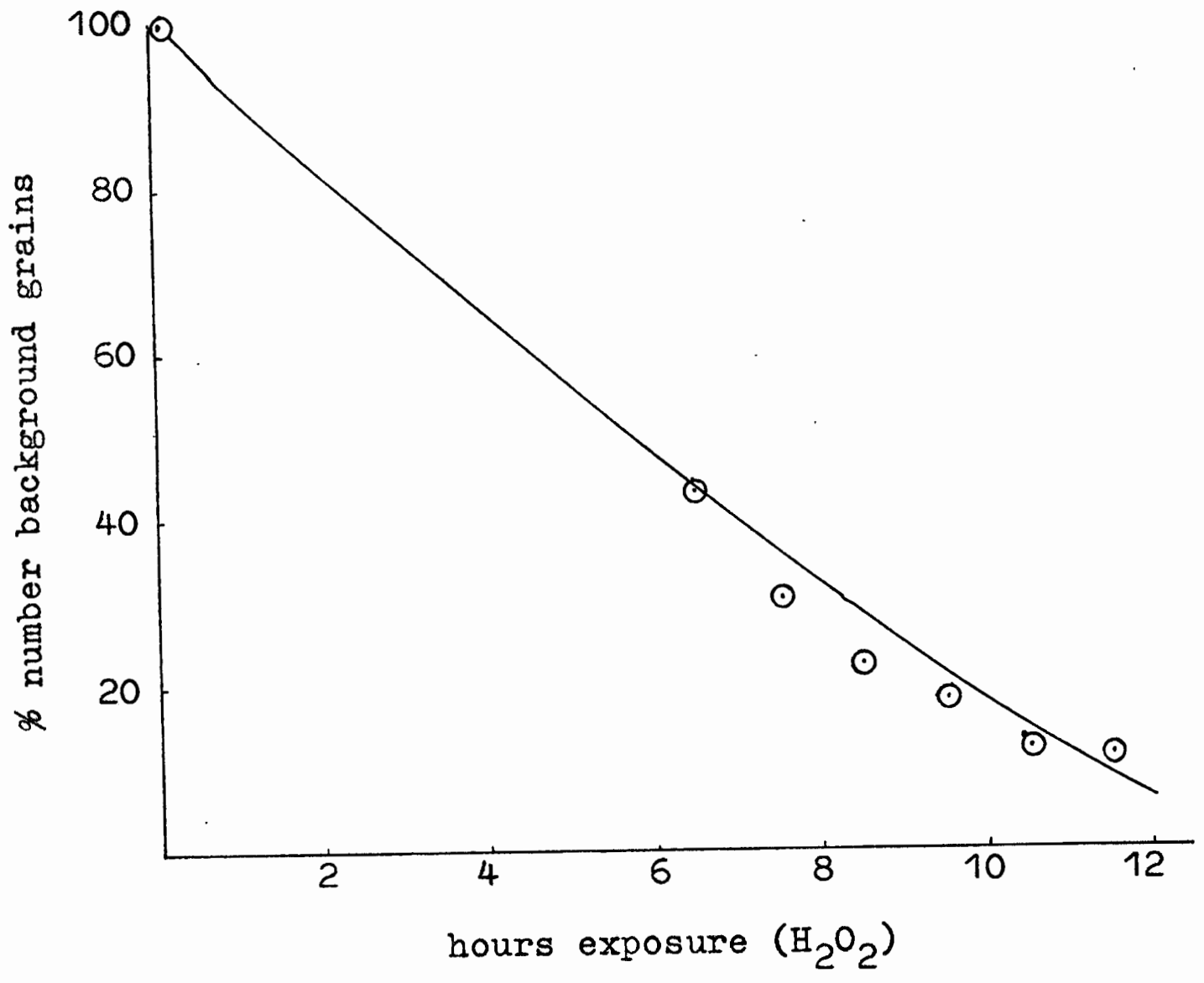

Figure 1. The reduction in number of background grains (as $\%$ of control) per $1000 \mathrm{x}$ field as a function of length of exposure to vapors of a $3.5 \%$ solution of hydrogen peroxide. 
results in an optimum number of tracks being recorded. Drying for 8 hours or more results in a secondary increase in background levels (Fig. 2).

After drying for 4 hours they are placed in plastic slide boxes along with a few grains of dried sitica gel, which removes remaining traces of water. The slide boxes are placed in a light proof container and are transferred to a refrigerator where serial exposures are carried out at $4^{\circ} \mathrm{C}$.

Development of the exposed emulsion is carried out in a 1:1 solution of Kodak D-19 developer and distilled water.for 9 minutes followed by a 5 minute $1 \%$ acetic acid stop bath. Fixation is carried out for 30 minutes in a 25 - 30\% solution of sodium thiosulfate (commercial fixatives are too strong), with a final rinse in distilled water for 25 minutes. The temperature of all solutions is $20^{\circ} \mathrm{C}$. Even small variations in temperature among the solutions causes the emulsion to contract and/or expand whereupon the emulsion separates from the slide. Development for shorter periods results in incomplete development of tracks (Fig. 3) while development for longer periods (or higher temperatures) results in an unacceptable background level. In addition, with longer development times the developed grains become too large, making track identification difficult. After the final distilled water rinse the slides 


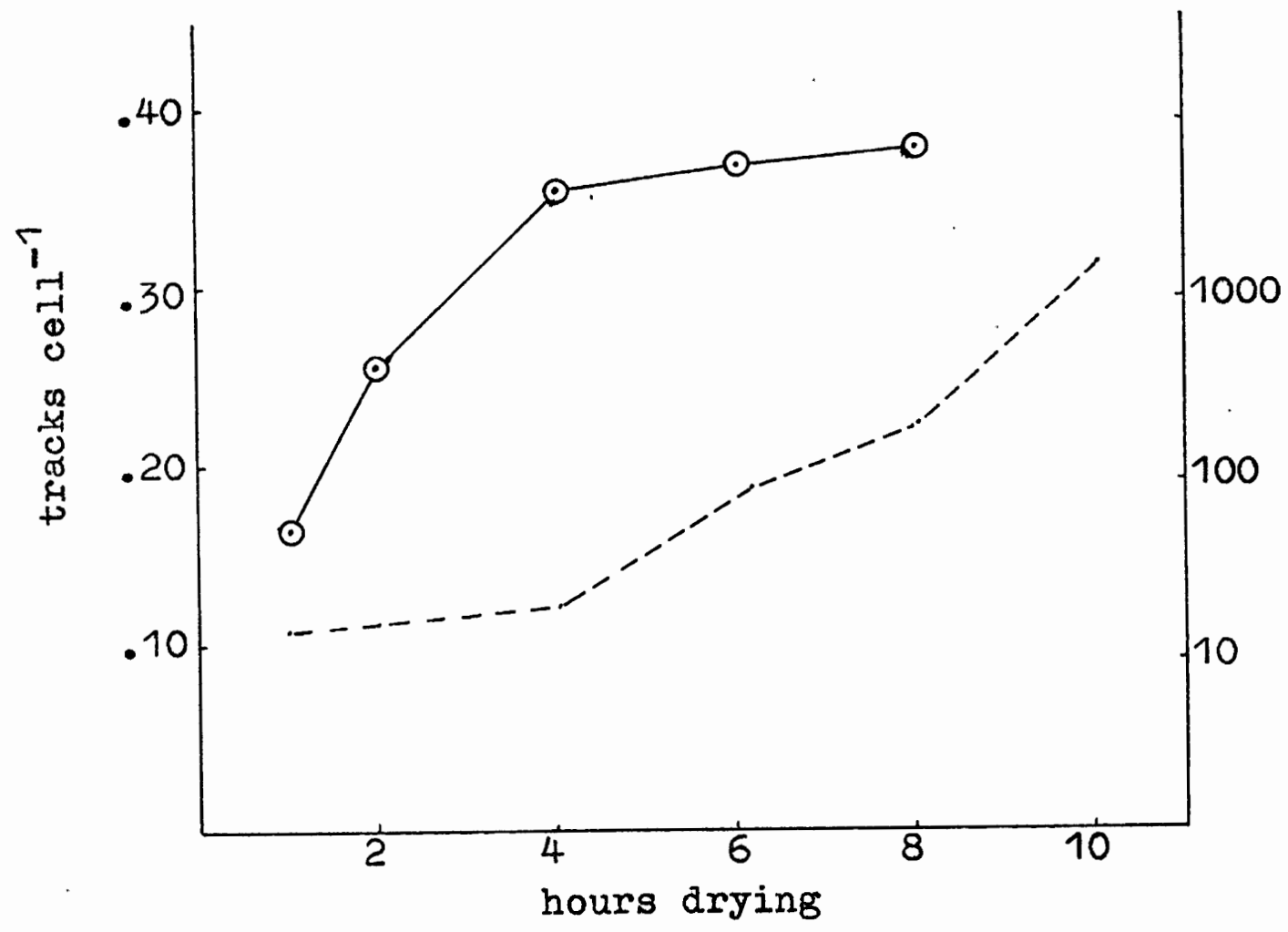

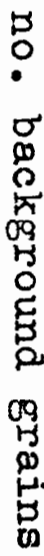

Figure 2. Relation between tracks per cell registered and drying time. Drying for four hours removes essentially all remaining peroxide. (_.....- Secondary increase in number of background grains per $1000 \mathrm{X}$ field). 


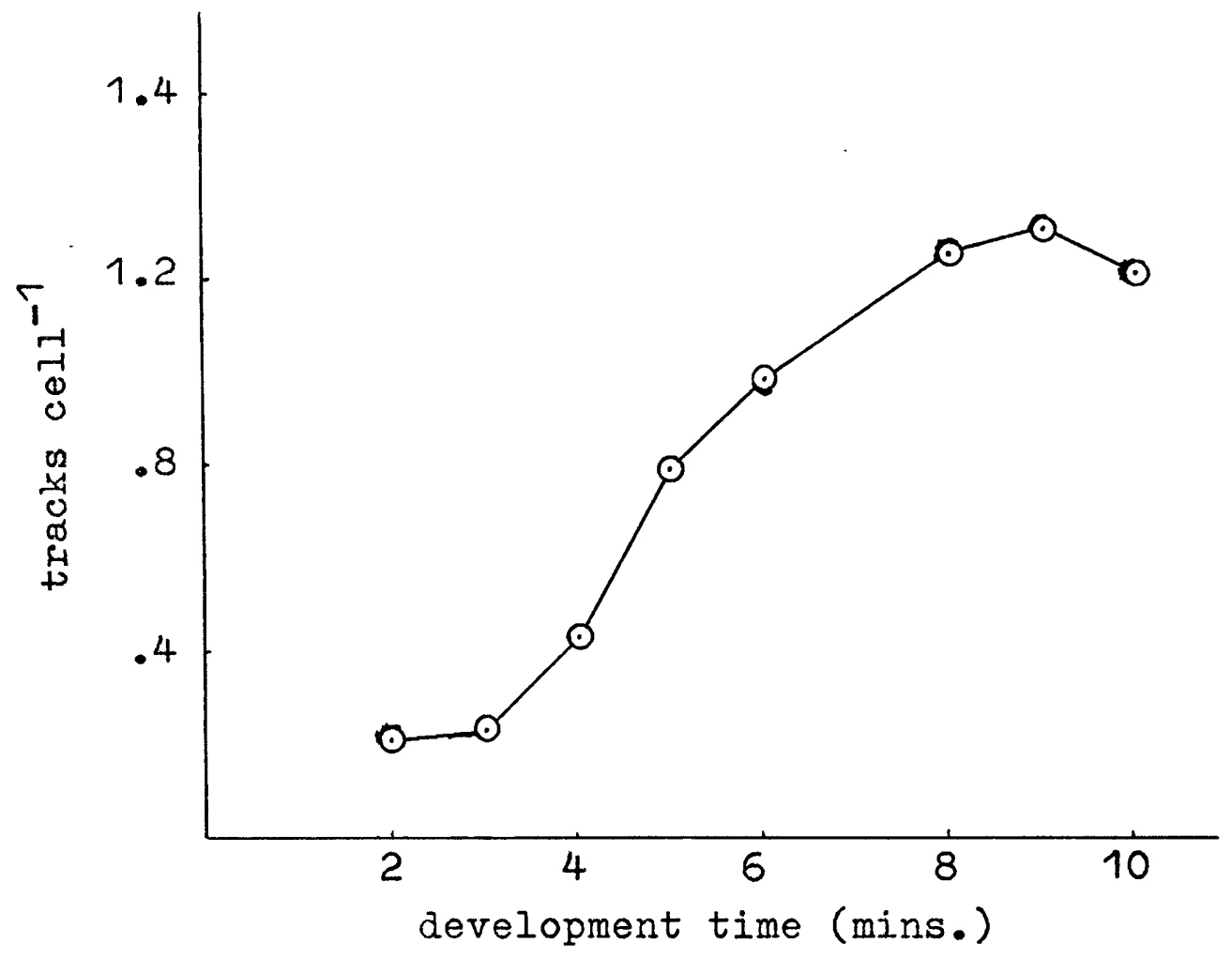

Figure 3. Relation between number of tracks registered per cell versus development time in a 1:1 solution of $\mathrm{D}-19$ and distilled water. Development for 9 minutes at $20^{\circ} \mathrm{C}$ results in an optimum number of tracks being recorded. 
are dried in a dust free atmosphere. A drop of $30 \%$ glycerin is placed on the emulsion and a cover slip added. After drying for a day this forms a permanent mount and also reswells the emulsion to its original thickness which facilitates track recognition. The emulsion must be at least 25 microns thick to register complete tracks. The above developing conditions are applicable to emulsions between 25 and 100 microns in thickness.

The preparation is viewed under oil immersion with phase contrast microscopy. A beta track is defined as any four (or more) silver grains developed in a row and is considered to originate from a cell if the track can be traced to within 5 microns of that cell (Rogers, 1969) Fig. 4). Five-hundred individuals per species are observed for each exposure and the number of tracks tabulated. The mean number of tracks for each exposure is plotted against exposure time and linear regression analysis yields the best estimate of the cellular decay rate for that species.

A quantitative evaluation of the number of disintegrations registered per cell includes the statistics of the decay process, variations in the uptake of the cells, and absorption by the specimen. If the carbon fixation rates of the individual cells of a species reflect a normally distributed population mean, the frequency 
Figure 4. Phase contrast photomicrograph of Selenastrum cell in developed autoradiograph. Arrow indicates track. Magnification $500 \mathrm{X}$. 
distribution of the cellular disintegration rate will fit a Poisson model because the disintegrations are a rare and random occurrence. Analysis confirms that the tracks obtained with autoradiography fit the expected distribution (Table I). The statistical significance is tested with a $\chi^{2}$ computation. The data are transformed before statistical procedures requiring a normal distribution are applied. The confidence limits for the means are calculated following Sokal and Rohlf (1969) by :

$$
\text { C.I. }=\left(t\left(s_{x}^{2} / n\right)^{1 / 2}\right)^{2}
$$

where $n$ is the number of cells observed, $s_{x}^{2}$ the variance of the transformed variable, and the student's $t$ for significance level desired. Estimates for selfabsorption are made on the basis of data from Hendler (1959) and calculations by Knoechel and Kalff (1976). 


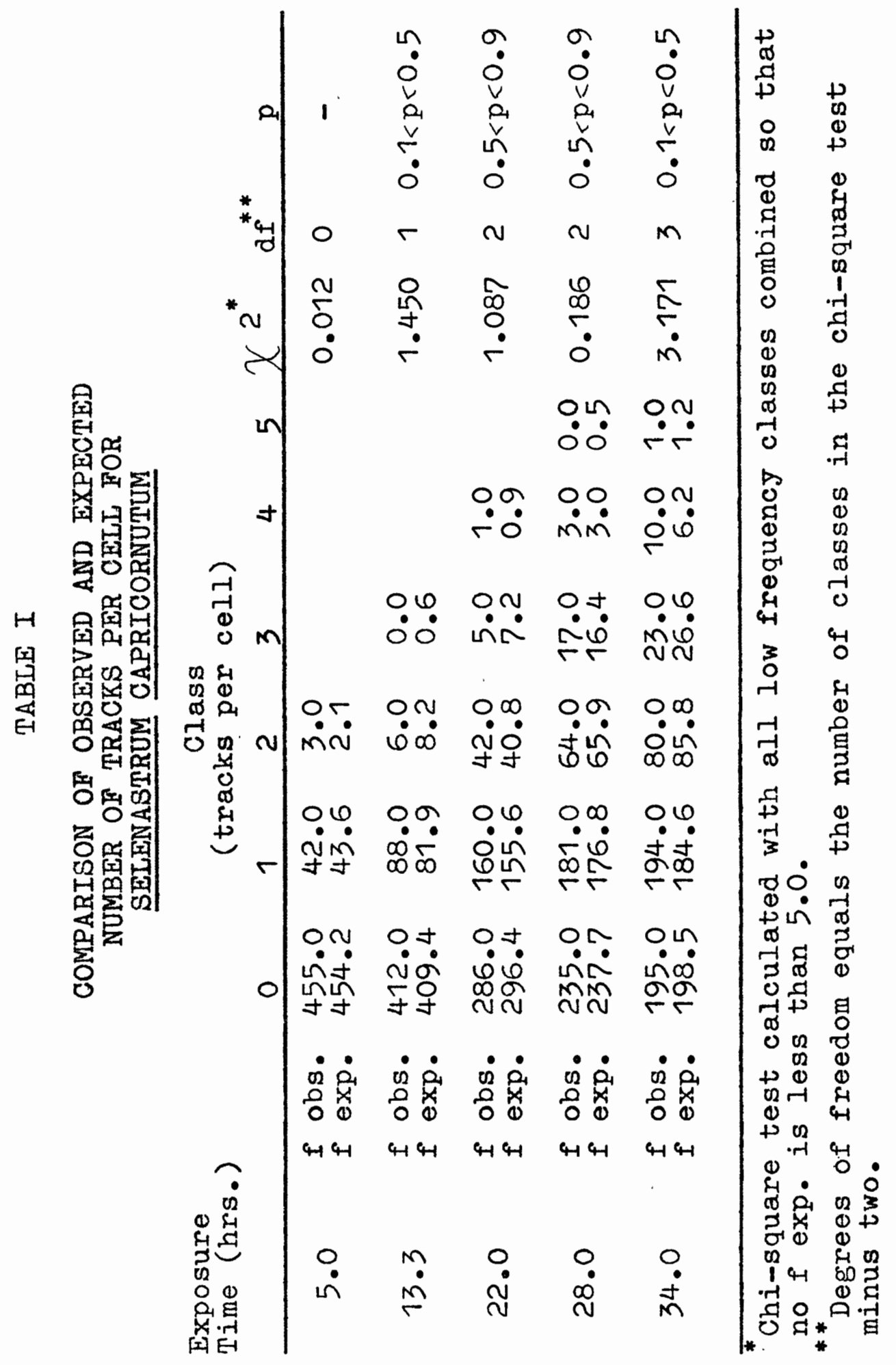




\section{RESUITS}

The activity obtained from track counts of a labelled Selenastrum culture compared favorably with that obtained through scintillation counting. Estimated activity of the particulate fraction of the culture by scintillation counting was $1370 \mathrm{dpm} \mathrm{ml}^{-1}(\mathrm{n}=7)$. Linear regression analysis of autoradiograms representing five different exposure times yielded $y=0.0302 x-0.1191$ (Fig. 5). Volumetric disintegration rate was computed from the slope by,

(2) $\left(0.0302\right.$ tracks cell $\left.{ }^{-1} \mathrm{hrs}^{-1}\right) \mathrm{x}$

$$
\frac{\left(1.05 \times 10^{6} \text { cells } \mathrm{ml}^{-1}\right)}{(.86)(.98)\left(60 \text { mins. } \mathrm{hr} .^{-1}\right)}=1255 \mathrm{dpm} \mathrm{ml}^{-1}
$$

where 2 corrects for the source:emulsion geometry, .86 for the percentage of beta particles with insufficient energy to leave a four grain track (Levi and Rogers, 1969), and .98 for absorption by the specimen (Hendler, 1959; Knoechel and Kalff, 1976). The autoradiographic value agrees well with the activity as determined by scintillation counting.

Autoradiographic analysis of the productivity of a mixed species culture allows the total productivity to be partitioned among the constituent species. To 


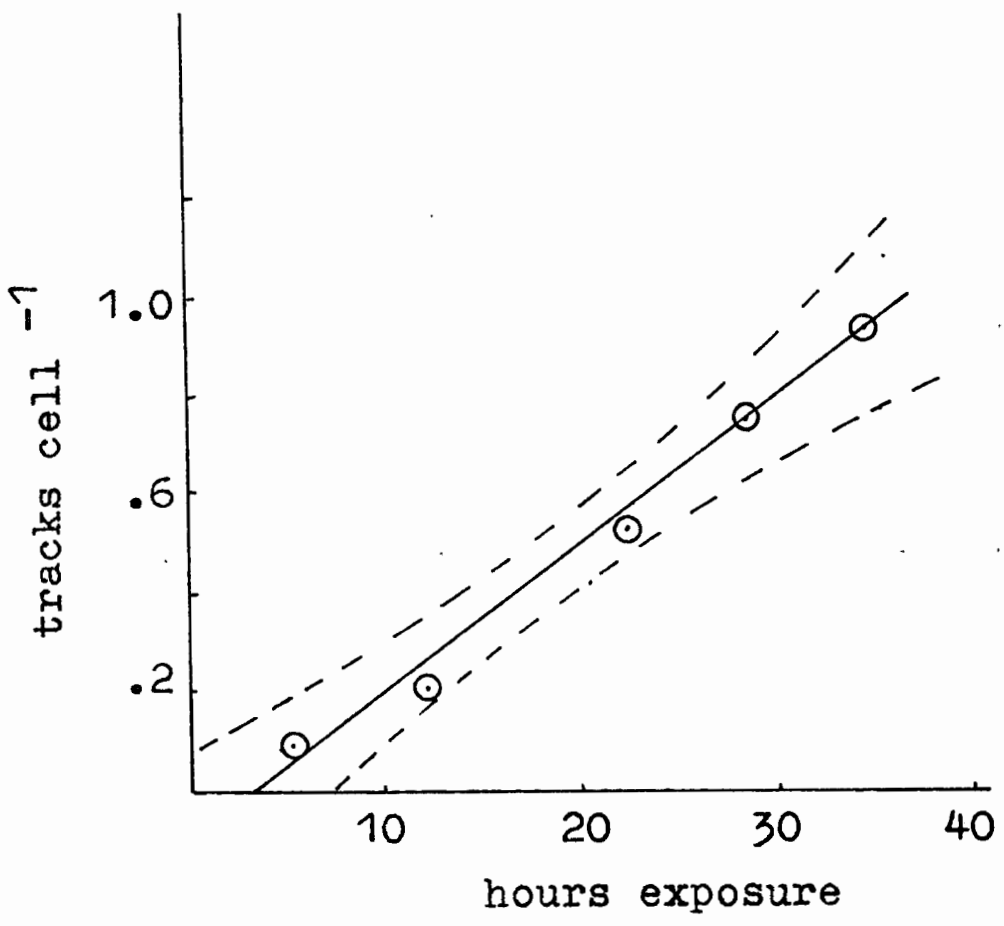

Figure 5. Relation between average number of tracks per cell and exposure time for Selenastrum. Linear regression analysis yields the best estimate of the cellular decay rate. $(y=0.0302 x-$ $0.1191 ; r=.98)$. Regression curve is drawn with $\pm 95 \%$ confidence limits. Data from Table I. 
demonstrate this Selenastrum and Chlorella were cultured together, inoculated with $.15 \mu \mathrm{C}$ carbon-14, and the productivity of each measured through track autoradiography. Relative productivity $\left(P_{i}\right)$ for each species was calculated using,

$$
P_{i}=\frac{\left(T_{i} N_{i}\right) / A_{i}}{\sum_{i}\left(T_{i} N_{i}\right) / A_{i}}
$$

where $T_{i}$ is the averase rate of track production per species, $N_{i}$ the concentration of the species in unit volume, and $A_{i}$ the self-absopption coefficient.

The results of the autoradiographic analysis are presented in Figures 6 and 7 (Table II). The disintegration rate for Chlorella $\left(1.14 \times 10^{6}\right.$ cells $\mathrm{ml}^{-1}$ ) was estimated as 0.0060 tracks $\operatorname{cell}^{-1} \mathrm{hr} . \mathrm{r}^{-1}$ and for Selenastrum $\left(4.85 \times 10^{5}\right.$ cells $\left.\mathrm{ml}^{-1}\right) 0.0115$ tracks cell ${ }^{-1}$ hr.:- Chlorella accounts for $55 \%$ and selenastrum $45 \%$ of the total productivity of the culture.

The relative productivity of each species was also calculated from growth rate data using literature values for cell weights. The r-value for Selenastrum (2.688 x $10^{-8} \mathrm{mg} \operatorname{cell}^{-1}$, Torien and Huang, 1973) was $0.036 \mathrm{hr}^{-1}$ and for Chlorella $\left(8.542 \times 10^{-9} \mathrm{mg} \mathrm{cell}{ }^{-1}\right.$, Myers, 1946) $0.051: \mathrm{hr}^{-1}$. Assuming that each contains proportionately equivalent amounts of carbon, Chlorella accounts for $51 \%$ and Selenastrum $49 \%$ of the total productivity. 
TABLE II

THE MEAN NUMBER OF TRACKS (X) SCORED FOR SELENASTRUM AND CHLORELIA FOR EACH OF FOUR EXPOSURE TIMES

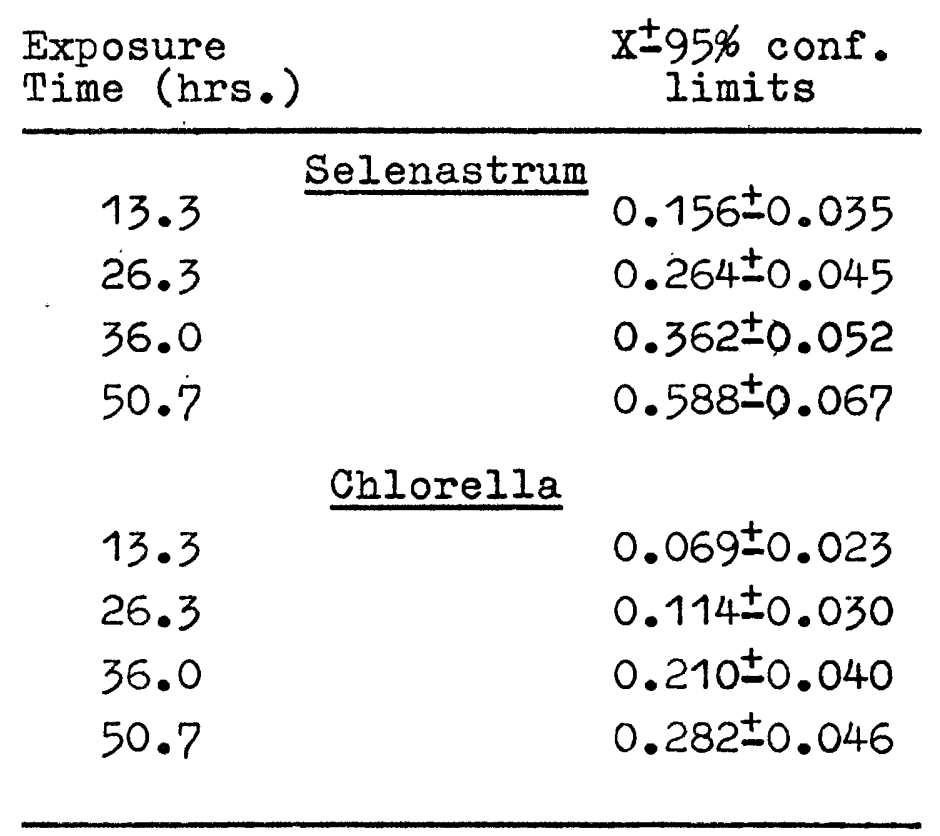




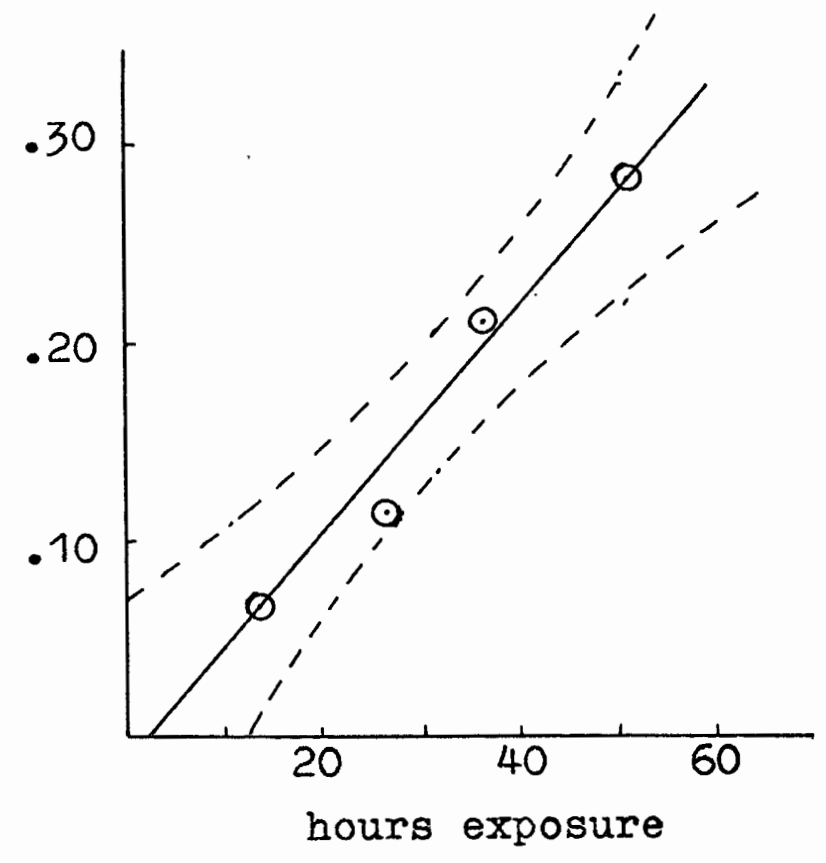

Figure 6. Relation between average number of tracks per cell and exposure time for Chlorella. Regression curve $(y=0.0060 x-0.0192 ; r=.97)$ drawn with $\pm 95 \%$ confidence limits. Data from Table II. 


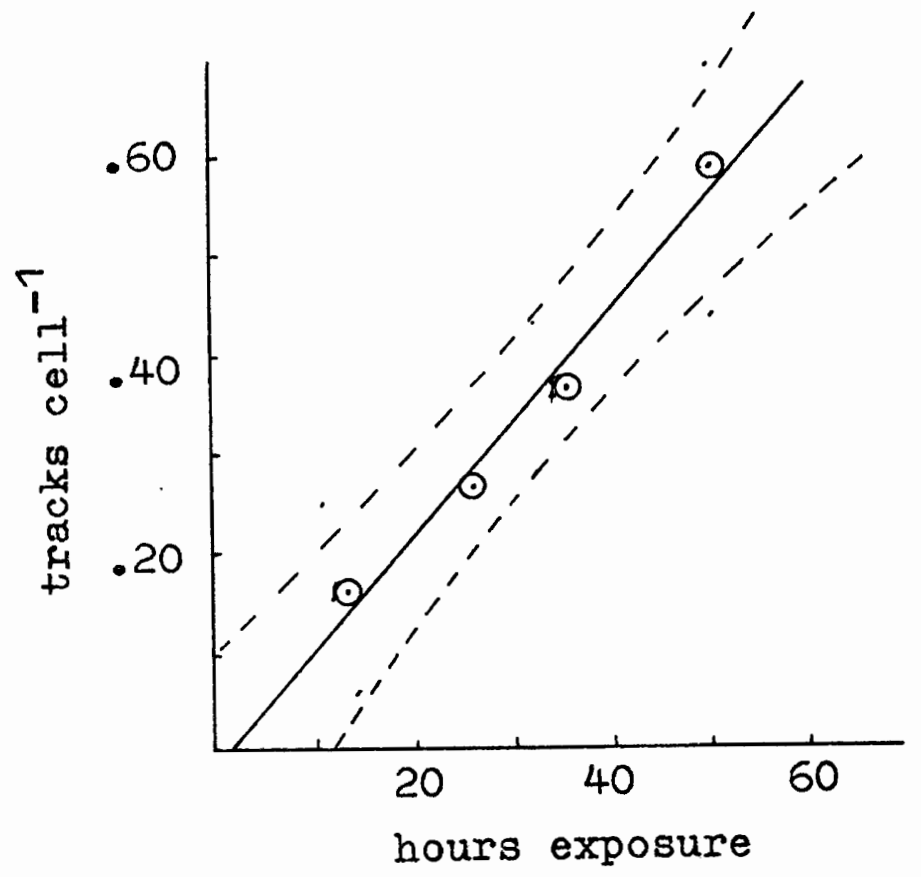

Figure 7. Relation between average number of tracks per cell and exposure time for Selenastrum. Regression curve ( $y=0.0115 x-0.0211 ; r=.97)$ drawn with $\pm 95 \%$ confidence limits. Data from Table II. 
Whether the carbon fixation rates measured with ${ }^{14}$ C-productivity represent gross or net productivity depends upon the nature of the uptake of tracer in the dark bottle. Many investigators have concluded that the carbon-14 technique measures something between the net and gross productivity, depending on experimental conditions (Goldman, 1969). The presence of activities above background levels in the dark sample may be the result of one or a combination of three processes: 1) uptake of ${ }^{14} \mathrm{CO}_{2}$ by the algae, 2) uptake of radioactive organic contaminents present in the stock solution of $\mathrm{Na}^{14} \mathrm{CO}_{3}$ by bacteria, or 3) the adsorption of tracer on detrital matter. The incomplete removal of free inorganic carbon from the medium during acidification and bubbling is probably not significant (Sharp, 1977). Analysis of the uptake of tracer by Chlorella in the dark sample was investigated with autoradiography.

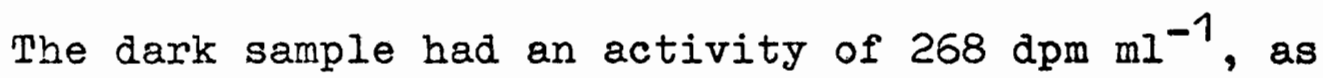
determined by scintillation counting. The cellular uptake of tracer from track counts, when converted to a volumetric disintegration rate was $99 \mathrm{dpm} \mathrm{ml}^{-1}$. (Observation of a similar number of cells grown in tracer free medium resulted in no tracks being observed.) Since the culture was non-axenic, this may represent either uptake by the algal cells or the uptake of organic matter by bacteria attached to the algal cell 
wall.

In addition to uptake of tracer due to biological activity tracer is adsorbed on detrital material. The adsorption of tracer onto particles is routinely observed in autoradiographs. The amount of adsorbed activity appears to be related to the strength of the radiocarbon inoculum.

In conclusion, these results demonstrate the applicability of track autoradiography in determining the rate of carbon uptake of different algal species. This technique could be of value in determining the pathways of energy flow within natural phytoplankton communities thus providing data which may be of value in the investigation of community dynamics. 


\section{REFERENCES}

Atkins, W.R.G. 1923. "Phosphate Content of Waters in Relationship to growth in its Biological Relation," J. Marine Biol. Assoc. U.K. 12: 717-771.

Berriman, R.W., R.H. Herz, and G.W. Stevens 1952. "Densitometric Autoradiography, "Brit. J. Radiol. 23: 472-481.

Brylinski, M. and K.H. Mann 1973. "An Analysis Governing Productivity in Lakes and Reservoirs," Limnol. \& Oceanogr. 18: 1-14.

Caro, I.G. 1964. "High Resolution Autoradiography," Methods in Cell Physiology vol. I p. 327-363.

Cooper, D.C. 1973. "Enhancement of Net Primary Productivity by Herbivore Grazing in Aquatic

Laboratory Microcosms," Limnol. \& Oceangr. 18: $31-37$.

Culver, D.A. and G.J. Brunsill 1969. "Fayetteville Green Lake V. Studies of Primary Production and Zooplankton in a Meromictic Marl Lake, "Iimnol. \& Oceanogr. 14: 862-873.

Environmental Protection Agency 1971. Algal Assay Procedure Bottle Test. National Eutrophication Research Program.

Findenegg, I. 1969. "Relationship Between Standing Crop and Primary Productivity, "In C.R. Goldman (ed.) , Primary Productivity in Aquatic Beosystems, p. 273-289, Univ. of California Press, Berkeley.

Findenegg, I. 1969. "Factors Controlling Primary Productivity Especially with Regard to Water Replenishment, Stratification, and Mixing," In C.R. Goldman (ed.), Primary Productivity in Aquatic Ecosystems, p. 311-324, Univ. of California Press, Berkeley.

Fog8, G.E. and Watt 1965. "The Kinetics of Release of Extracellular Products of Photosynthesis by Phytoplankton," In C.R. Goldman (ed.), Primary Productivity in Aquatic Ecosystems, p. 175-186, Univ. of California Press, Berkeley. 
Goldman, C.R. 1969. "Aquatic Primary Productivity," Amer. Zoologist 1: 31-42.

Gutelmacher, B.I. 1975. "Relative Significance of Some Species of Algae in Plankton Primary Productivity," Arch. Hydrobiol. 75: 318-328.

Hendler, R. 1959. "Self-Absorption Correction for Carbon-14," Science 130: 772-777.

Knoechel, R. and J. Kalff. 1975. "Algal Succession: The Cause of a Diatom Succession," Verh. Int. Ver. Limnol. 19: 745-754.

Knoechel, R. and J. Kalff. 1976. "The Applicability of Grain Density Autoradiography to the Quantitative Determination of Algal Species Production: a Critique," Limnol. Oceanogr. 21: 584-590.

Kodak, 1976. "Kodak Materials for Nuclear Physics and Autoradiography," Eastman-Kodak Co., Rochester, New York.

Leith, H. and R. Whitaker, (eds.) 1976. Primary Productivity of the Biosphere, Springer-Verlag, New York.

Levi, H. 1951. "Quantitative beta-Track Autoradiography of Single Cells," Exp. Cell Res. 7: 44-51.

Levi, H. 1954. "Autoradiography Using beta Emitters," Exp. Cell Res. Supp. 4: 207-210.

Levi, H. and A.W. Rogers. 196: " "On the Quantitative Evaluation of Autoradiograms," Mat. Fys. Medd. Dan. Vid. Selsk. 33 (11): 51.

Levinthal, C. and C.A. Thomas Jr. 1957. "Molecular Autoradiography: The beta-ray Counting From Single Virus Particles and DNA Molecules in Nuclear Enulsions," Biochimica et Biophysica Acta. 23: 453-465.

Maguire, R.C. 1971. "The Relative Importance of Species and Individual Productivity in Phytoplankton," Ecol. 52: 903-907.

Malone, T.C. 1971. "The Relative Importance of Nanoplankton and Net Plankton as Primary Producers in Tropical and Oceanic and Neritic Phytoplankton Communities," Limnol. Oceanogr. 16: 633-639. 
Morris, I. C.M. Yenych, and C.S. Yentch 1971. "Relationship Between Iight $\mathrm{CO}_{2}$ Fixation and Dark $\mathrm{CO}_{2}$ Fixation by Matine Algae," Limnol. Oceanogr. 16? 854-868.

Myers, J. 1946. "Culture Conditions and the Development of the Photosynthetic Mechanism." III. Influence of Iight Intensity on Cellular Characteristias of Chlorella. J. Gen. Physiol. 29: 419-427.

Riley, G.A. 1944. "The Carbon Metabolism and Photosynthetic Efficiency of the Earth as a Whole," American Scientist 32: 129-134.

Rogers, A.W. 1969. Techniques of Autoradiography, Elsevier Publishing Co., New York.

Schindler, C. 1972. "Acidification and Bubbling as an Alternate to Filtration in Determining Phytoplankton Production by the C-14 Method," J. Fish. Res. Bd. Can. 29: 1627-1631.

Sharp, J. 1977. "Excretion of Organic Matter by Marine Phytoplankton: Do Healthy Cells Do It?" Iimnol. Oceanogr. 22: $381-400$.

Sheldon, R.W., W.H. Sutcliffe Jr., and A. Prakash 1973. "The Production of Particles in the Surface Waters of the Ocean with Particular Reference to the Sargasso Sea," Limnol. Oceanogr. 18: 719-733.

Slawyk, G., Y. Colles, and J.C. Auclair 1977. "The Use of $\mathrm{C}-13$ and $\mathrm{N}-15$ Isotopes for the Simultaneous Measurement of Carbon and Nitrogen Turnover Rates in Marine Phytoplankton," Iimnol. Oceanogr. 22: $925-932$.

Sokal, R.R. and F.J. Rohlf 1969. Biometry: The Principles and Practice of Statistics in Biological Research, Freeman Publishing Co., New York.

Steeman-Nielsen, E. 1952. "The Use of Radiocarbon (C-14) for Measuring Organic Production in the Sea," J. Cons. Ints. Explor. Mer. 19: 309-328.

Stross, R.G. and S.E. Pemrick 1974. "Nutrient Uptake Kinetics in Phytoplankton: A Basis for Niche Separation," J. Phycol. 10: 164-169. 
Thomas, R.J., C.R. Hipkin and P.J. Syrett 1977. "The Interaction of Nitrogen Assimilation with Photosynthesis in Nitrogen Deficient Cells of Chlorella," Planta 133: 9-15.

Tilzer, M.M. 1973. "Diurnal Periodicity in the Phytoplankton Assemblage of a High Mountain Lake," Limnol. Oceanogr. 18: 15-28.

Torien, D.F. and C.H. Huang 1973. "Algal Growth Production Using Kinetic Growth Constants," Water Res. 7: 1673-1681.

Vollenweider, R・A., (ed.) 1969. A Manual on Methods for Measuring Primary Productivity in Aquatic Environments. IBP Handbook No. 12. F.A. Haus Co., Philadelphia.

Watt, W. 1971. "Measuring the Primary Production Rates of Individual Phytoplankton Species in Natural Populations," Deep Sea Res. 18: 329-339.

Westlake, D.F. 1969. "Comparability of Productivity Data," In C.R. Goldman (ed.) Primary Productivity in Aquatic Ecosystems, p. 220-224, Univ. of California Press, Berkeley.

Winkler, R. 1888. "Iodometric Method for Determining Dissolved Oxygen Concentrations, "In Standara Methods for the Examination of Water and WasteWater, American Public Health Association, Washington, D.C. 